\title{
ILLINOIS STATE GEOLOGICAL SURVEY RADIOCARBON DATES IV
}

\author{
DENNIS D. COLEMAN
}

\section{Illinois State Geological Survey, Urbana, Illinois 61801}

This date list includes all samples processed from December 1970 through November 1971 at the Illinois State Geological Survey Radiocarbon Dating Laboratory. The benzene liquid scintillation method of Noakes, Kim, and Stipp (1965), and Noakes, Kim, and Akers (1967) was used. A new benzene synthesis system has been completed, and several changes in the sample preparation procedure have been made since the last date list report (Coleman, 1972). A bricf summary of the benzene synthesis and sample pretreatment techniques used to determine the dates reported here follows.

All organic samples are boiled in $2 \mathrm{~N}$ HCl for a minimum of 2 hours and thoroughly rinsed. Wood and fibrous peat samples are then boiled in $0.5 \mathrm{~N} \mathrm{NaOH}$ for 2 hours or more and rinsed several times with boiling water. Wood samples expected to contain large amounts of volatile material are pyrolized under $\mathrm{N}_{2}$ before combustion to prevent explosions. Collagen is separated from bone samples by digestion in $1 \mathrm{~N}$ Hel under partial vacum. The insolutle residue is then washed with $0.5 \mathrm{~N} \mathrm{NaOH}$ and centrifuged.

Organic samples are burned in a Vycor tube under a positive $O$. pressure of a. l psi. The $C\left(C_{2}\right.$ is purified by passing it successively through the following: platinized asbestos at ca. $5500^{\circ} \mathrm{C}, \mathrm{CuO}$ at $600^{\circ} \mathrm{C}$, a $0.5 \mathrm{~N} \mathrm{ANO}$ solution, and a solution of $7.3 \mathrm{~g} \mathrm{Na}_{2} \mathrm{Cr}_{2} \mathrm{O}_{7}$ in $50 \% \mathrm{H}_{2} \mathrm{SO}_{4}$. Water is then renoved in a tap cooled by Dry Ice-isopropanol, and the CO. frozen out with liquid nitrogen. The synthesis of acetylene and its trimcrization to benzenc is carried out as described by Kim and Ruch (1969), and Kim, Ruch, and Kempton (1969).

$\mathrm{CO}$, is cvolved from arbonate samples with $50 \%, \mathrm{H}_{3} \mathrm{PO}_{1}$. The NBS oxalic acid reference standard is converted to $\mathrm{CO}_{2}$ by wet oxidation with great care to achicve complete reaction.

All samples are counted in a modified Packard 'Tri-Carb Model 3375 liquid scintillation spectrometer operated at $1^{\circ}$ C. Butyl P'BI dissolved in toluene $(50 \mathrm{mg} / \mathrm{ml})$ is used as a scintillator. Samples expected to have ages greater than 40,000 years s.p. are comted in a $20 \mathrm{ml}$ quartz vial containing $16 \mathrm{ml}$ of sample benzene and $4 \mathrm{ml}$ of scintillator solution. 'I his vial gives a counting figure of merit $\left(E^{-1} / \mathbf{B}\right)$ of ca. 520. Younger samples are counted in a $10 \mathrm{ml}$ low-potassium glass vial containing up to $8 \mathrm{ml}$ of sample benzene and 2 ml of scintillator solution. If $8 \mathrm{ml}$ of sample benzene is not available, spectrodiemical grade benzene is added. This vial has a figule of merit of ca. 790. Backgrounds are counted in the same vials as samples using spectrochemical grade benrene. Benzene prepared from the combustion of coal is also comted periodically to insure that there is no contanination during synthesis. Samples are 
counted for a minimum of 24 hours, and backgrounds are counted bcfore and after each sample. Benzene prepared from NBS oxalic acid reference standard is counted every 6 months to determine the efficiency of the instrument and a "hot sample" prepared from commercially available $\mathrm{C}^{14}$-enriched benzene is counted monthly to guard against instrument drift.

All ages are calculated using a $\mathrm{C}^{14}$ half-life of 5568 years. Errors $\left(l_{\sigma}\right)$ reported account only for uncertaintics in activity measurements of the sample, standard, and backgrounds. Samples with net count rates $<4_{\sigma}$ are reported as mininum ages. Samples with net count rates $<4_{\sigma}$ below the reference standard are considered modern, and for these,

values for $\delta \mathrm{C}^{14}$ are reported where $\delta \mathrm{C}^{14}=\frac{A_{\text {sample }}-A_{\text {std }}}{A_{\text {std }}} \times 1000$, and $A$ is net cpm per gm benzene. No corrections have been made for isotopic fractionation or atmospheric $\mathrm{C}^{1.4}$ fluctuations.

Chao Li Liu assisted in sample preparation. All requests for analyses were evaluated by an Isotopic Analysis Committee consisting of J. P. Kempton (chairman), Charles Collinson, R. E. Bergstrom, D. D. Coleman, and J. C. Frye.

\section{SAMPLE DESCRIPTIONS}

J. GEOLOGIC SAMPIES

A. Illinois and Lake Michigan

\section{ISGS-61. Morris North Section}

$24,990 \pm 280$

Wood from silt in Grundy Co., SE $1 / 4$ NE $1 / 4$ NE $1 / 4$ Sec. 33, T.34N, R.7E, on $\mathrm{N}$ edge of Morris, Illinois $\left(41^{\circ} 23^{\prime} 00^{\prime \prime} \mathrm{N}\right.$ Lat, $88^{\circ} 25^{\prime} 15^{\prime \prime} \mathrm{W}$ Long). From Peddicord Formation (Willman et al., 1971). Coll. 1970 by J. C. Frye and H. B. Willman; subm. by J. C. Frye, Illinois State Geol. Survey. Comment (J.C.F.): confirms Farmdalian age of lake silts of Peddicord Formation and correlation with similar lake sediments at Wedron Section.

\section{Garden Plain series}

\section{ISGS-106. Upper $60 \mathrm{~cm}$}

$$
\begin{aligned}
& 34,630 \pm 550 \\
& 32,680 \text { в.C. }
\end{aligned}
$$

\section{ISGS-64. Middle $15 \mathrm{~cm}$}

$39,000 \pm 1100$ 37,050 B.C.

\section{ISGS-98. Lower $30 \mathrm{~cm}$}

$41,900 \pm 1300$

Organic-rich silt from Whiteside Co., SE1/4 SE1/4 NE1/4 Sec. 3, T.20N, R.3F, $4 \mathrm{~km} \mathrm{~S}$ of Garden Plain, Illinois ( $41^{\circ} 45^{\prime} \mathrm{N}$ Lat, $90^{\circ} 9^{\prime} \mathrm{W}$ Long). From $1.2 \mathrm{~m}$ organic-rich silt unit below Peoria Loess and above till. Coll. 1971 and subm. by I. E. Odom, N. Illinois Univ., De Kalb. Com- 
ment (I.E.O.): 1st reported occurrence of deposits in W Illinois equivalent to Plano Silt Member of Wimnebago Formation. Ages are possible minimum and maximum for deposition of Plano Silt Member in area.

\section{ISGS-97. Union Grove}

$37,420 \pm 710$ 35, 470 в.c.

Organic-rich silt from Whiteside Co., SW1/4 NW1/4 NW1/4 Sec. I0, T.21N, R.4E, $0.8 \mathrm{~km}$ SW of Union Grove, Illinois $\left(41^{\circ} 45^{\prime} 45^{\prime \prime} \mathrm{N}\right.$ Lat, $90^{\circ} 2^{\prime} \mathrm{W}$ I Long). Top $30 \mathrm{~cm}$ of $1.4 \mathrm{~m}$ peat bed. Coll. 1971 and subm. by I. E. Odom. Comment (I.E.O.): age equivalent to that of Plano Silt Member in E Illinois and agrees with dates from Garden Plain series.

\section{Vandalia Core series, Pittsburg Basin}

\section{ISGS-65. J-3, 255 to $260 \mathrm{~cm}$ depth}

\section{ISGS-67. J-4, 263 to $265 \mathrm{~cm}$ depth}

ISGS-71. J-5, 295 to $297 \mathrm{~cm}$ depth

Organicrich silt from Fayette Co., SW $1 / 4 \mathrm{NE}_{1 / 4}$ SW1/4 Sec. 3, T.5N, R.IW, $4.5 \mathrm{~km} \mathrm{SSW}$ of Hagarstown, Illinois $\left(38^{\circ} 54^{\prime} 00^{\prime \prime} \mathrm{N}\right.$ Lat, $89^{\circ} 11^{\prime}$ $30^{\prime \prime} \mathrm{W}$ Long). From Equality Formation, 4 to $5 \mathrm{~m}$ above Hagarstown Member of Glasford Formation. Coll. 1969 by A. M. Jacobs and H. E. Wright; subm. by A. M. Jacobs, Illinois State Geol. Survey. Comment $($ A.M.J.): pollen assemblages of samples are characterized by high values of nonarboreal pollen (ca. 50\%), and Quercus is dominant arboreal pollen type (Grüger, 1970). Grüger suggests that region, at time of deposition, was prairie with trees along river valleys or in oak savannas.

Relative position of ISGS-65 in core indicates date is ca. $9000 \mathrm{yr}$ too young. Interpolation with 6 other finite dates from site (R., 1970, v. 12 , p. $505 ; 1972$, v. 14, p. 150), using relative pollen frequency and depth as controls, indicates that ISGS-65 should be ca. 33,000 yr old.

Samples ISGS-67 and -71 show sedimentation rate in Pittsburg Basin during late Altonian Substage of $\mathrm{ca} .1 \mathrm{~cm} / 100 \mathrm{yr}$. Other dates from basin indicate same order of magnitude for rates of sedimentation.

Clay mineralogy of sediments below ISGS-67 indicate no appreciable loess deposition in area before late Altonian time (Jacobs, 1970).

\section{ISGS-68. Lake Michigan Core 212-2}

$$
3460 \pm 210
$$

$1510 \mathrm{B.c}$.

Organic-rich silt from core sample, $54 \mathrm{~km}$ ENE of Waukegan,

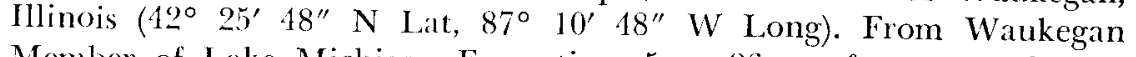
Member of Lake Michigan Formation, 5 to $26 \mathrm{~cm}$ from top of core. Coll. 1970 by D. L. Gross, J. A. Lineback, and H. V. Leland; subm. by D. L. Gross, Illinois State Gcol. Survey. Comment (D.L.G.): 1st date for Waukegan Member. Two previous dates from S Lake Michigan 
(R., 1972, v. 14, p. 149) were from underlying Lake Forest Member (Linclack et al., 1970).

ISGS-100. Lake Michigan Core 836-5

$910 \pm 140$

Wood in clayey silt from core sample, $19 \mathrm{~km} \mathrm{SW}$ of Benton Harbor, Michigan $\left(42^{\circ} 7^{\prime} 42^{\prime \prime} \mathrm{N}\right.$ Lat, $86^{\circ} 43^{\prime} 30^{\prime \prime} \mathrm{W}$ Long). From. Waukegan Member, 72 to $95 \mathrm{~cm}$ below top of Lake Michigan Formation. Coll. 1971 by J. A. Lineback et al.; subm. by J. 1 . Lineback, Illinois State Geol. Survey. Comment (J.A.L.): delta-like wedge of sediment along Michigan shore is relatively young and deposited from sediment carricd in by present-day rivers. Also inclicates more rapid sedimentation rate along $\mathrm{E}$ side of lake than in central and $\mathrm{W}$ portions.

ISGS-69. Parkland College

$13,980 \pm 200$ 12,030 в.C.

Silty peat from Champaign Co., SE1/4 NW $1 / 4$ SW $1 / 4$ Sec. 3, T.19N, R.8E, $4 \mathrm{~km} \mathrm{NW}$ of Champaign, Illinois $\left(40^{\circ} 7^{\prime} 57^{\prime \prime} \mathrm{N}\right.$ Lat, $88^{\circ} 17^{\prime} 30^{\prime \prime}$ W Long). From $8 \mathrm{~cm}$ silty peat overlain by $2.4 \mathrm{~m}$ of silty clay. Coll. 1970 by W. H. Johnson and L. R. Follmer; subm. by W. H. Johnson, Univ. Illinois. Comment (W.H.J.): dates organic accumulation in final stage of sedimentation in small lake on Champaign Moraine. Unit was buried by loess and slopewash.

\section{ISGS-74. Miller Creek}

$2850 \pm 80$

900 B.C.

Wood in clay from Alexander Co., N1/2 NE1/4 Sec. 9, T.15S, R.3W, $1.6 \mathrm{~km} \mathrm{NE}$ of 'Thebes, Illinois ( $37^{\circ} 13^{\prime} \mathrm{N}$ Lat, 89 $26^{\prime} \mathrm{W}$ Long). From $0.6 \mathrm{~m}$ sec. of sandy, silty clay overlain by $2.4 \mathrm{~m}$ alluvial and backwater silt and underlain by gravel. Coll. and subm. 1970 by W. F. Meents, Illinois State Gcol. Survey. Comment (W.F.M.): ca. $3 \mathrm{~m}$ of Holocene alluvium was deposited in Miller Creek in last $2850 \mathrm{yr}$.

\section{ISGS-78. Reynolds School}

$16,160 \pm 140$

14,210 B.c.

Wood in silt from Rock Island Co., NW1/4 SE $1 / 4$ SE $1 / 4$ Sec. 18 , T.16N, R.5W, $6.4 \mathrm{~km} \mathrm{SE}$ of Muscatinc, lowa $\left(41^{\circ} 22^{\prime} 30^{\prime \prime} \mathrm{N}\right.$ Lat, $91^{\circ}$ $00^{\prime} 00^{\prime \prime} \mathrm{W}$ Long). From tcrace silt related to Shellbyville Drift (Henry Formation). Coll. 1970 and subm. by R. C. Anderson, Augustana College, Rock Island, Illinois. Comment (R.C.A.): wood buried by sand dunes during or shortly after deposition of valley train, which extends down Mississippi River from maximum position of Woodfordian glacier in Green River Lowland. Date is minimum for terminal position (Atkinson-Temperance Hill Moraines) of Grcen River Sublobe.

\section{ISGS-79. Mahomet SW}

$21,670 \pm 130$

19,720 в.с.

Wood in organic-rich silt from Champaign Co., SW1/4 SE $1 / 4 \quad$ NW1 $_{1 / 4}$ Sec. 20, T.20N, R.7E, $2.4 \mathrm{~km}$ SW of Mahomet, Illinois $\left(40^{\circ} 9^{\prime} 21^{\prime \prime} \mathrm{N}\right.$ 
Lat, $88^{\circ} 26^{\prime} 20^{\prime \prime} \mathrm{W}$ Long). From Robein Silt. Coll. and subm. 1971 by W. H. Johnson. Comment (W.H.J.): silt overlain by 2 Woodfordian tills.

\section{ISGS-80. RMM-1}

$13,090 \pm 110$ 11,140 B.C.

Peat from Macon Co., SW $1 / 4$ NW1/4 NW1/4 Sec. 4, T.16N, R.4E, 3.2 $\mathrm{km}$ L of Oakley, Illinois $\left(99^{\circ} 50^{\prime} 43^{\prime \prime} \mathrm{N}\right.$ Lat, $88^{\circ} 46^{\prime} 1^{\prime \prime} \mathrm{W}$ Long). From small depression bordered on 3 sides by Cerro Gordo Moraine and overlain by glacial outwash. Coll. 1971 and subm. by R. M. Mason, Univ. Illinois. Comment (R.M.M.): date is minimum for formation of Cerro Gordo Moraine.

\section{Harmattan Strip Mine \#4 series}

Site in Vermilion Co., NE1/4 NE1/4 NW1/4 Sec. 4, R.19N, T.12W, $8 \mathrm{~km} \mathrm{~W}$ of Danville, Illinois $\left(40^{\circ} 08^{\prime} 42^{\prime \prime} \mathrm{N}\right.$ Lat, $87^{\circ} 43^{\prime} 38^{\prime \prime}$ W Long). Coll. 1971 by W. H. Johnson, D. L. Gross, L. R. Follmer, and A. M. Jacobs; subm. by W. H. Johnson.

\section{ISGS-81. L-17B}

$20,800 \pm 130$

\section{$\begin{array}{ll}\text { ISCS-81. L-17B } & 18,850 \text { B.c. }\end{array}$} Members.

\section{ISGS-83. L-16}

$20,500 \pm 210$

Wood from 18,550 в.c. Batestown Till Members.

Gencral Comment (W.H.J.): dates Glenburn Till Member of Wedron Formation as Woodfordian.

\section{ISGS-63. Higginsville}

$48,100 \pm 1700$

Wood tragments in silt from Vermilion Co., SW $1 / 4 \mathrm{SE} 1 / 4 \mathrm{NE} / 4 \mathrm{Sec}$. 26, T.21N, R.13W, $1.6 \mathrm{~km}$ NW of Higginsville, Illinois $\left(40^{\circ} 14^{\prime} 45^{\prime \prime}\right.$ $\mathrm{N}$ Lat, $87^{\circ} 46^{\prime} 30^{\prime \prime} \mathrm{W}$ Long). From organic-rich silt immediately below Glenburn Till Member of Wedron Formation. Coll. 1970 by W. H. Johnson and D. D. Coleman; subm. by W. H. Johnson. Comment (W.H.J.): organic-rich silt is Altonian and suggests overlying till (Glenburn Till Member) may also be Altonian. Regional stratigraphy and other radiocarbon dates (ISGS-81 and -83), however, indicate the Glenburn is Woolfordian in age.

\section{ISGS-85. Fairmount Quarry}

$21,420 \pm 720$

Wood fragments in gray silt fiom Vemilion Sec. 20, T.18N, R.13W, $5.6 \mathrm{~km} \mathrm{SW}$ of Fairmount, $\mathrm{N}$ Lat, $87^{\circ} 51^{\prime} 45^{\prime \prime} \mathrm{W}$ Long). From $2 \mathrm{~m}$ unit of and gravel overlain by $2.1 \mathrm{~m}$ till and underlain by $3.4 \mathrm{~m}$ till; entire sec. believed to be Batestown Till Member of Wedron Formation. Coll. 
1971 and subm. by W. H. Johnson. Comment (W.H.J.): date is older than Batestown Till Member, as indicated by regional stratigraphy and radiocarbon dates (ISCS-81 and -83). Either old wood from Robein Silt was incorporated into silt, or interpretation of stratigraphy is incorrect and silt and lower till are not from Batestown Till Member.

ISGS-82. Clear Creek \#2 $>48,000$

Wood in carbonaceous silt from Putnam Co., NW1/4 NW1/4 NE1/4

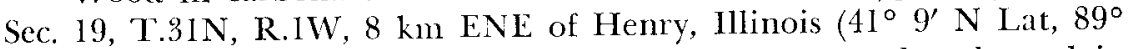
$16^{\prime} \mathrm{W}$ Long). From organic-rich silt overlying thick sand and overlain by calcareous till. Coll. 1971 by J. C. Frye, A. B. Leonard, and H. B. Willman; subm. by J. C. Frye. Comment (J.C.F.): date suggests that silt and containcd molluscan fauna are probably Illinoian rather than Altonian as had been suspected.

\section{Big Ridge series}

\section{ISG-84. Wood P7304}

$$
\begin{aligned}
& 20,600 \pm 220 \\
& 18,650 \text { в.C. }
\end{aligned}
$$

\section{ISGS-87. Peat P7304}

Site in Saline Co., SE $1 / 4 \mathrm{NW}_{1 / 4} \mathrm{NW}_{1 / 4} \mathrm{Sec}$. 19, T.9S, R.7E, $11 \mathrm{~km}$ $\mathrm{W}$ of Equality, Illinois $\left(37^{\circ} 43^{\prime} 54^{\prime \prime} \mathrm{N}\right.$ Lat, $88^{\circ} 14^{\prime} 52^{\prime \prime} \mathrm{W}$ Long). From Equality Formation. Coll. 1971 by J. C. Frye, A. B. Leonard, and H. B. Willman; subm. by J. C. Frye. Comment (J.C.F.): dates upper part of high-level fill of Lake Saline and indicates lower part of fill is older than previously believed. Wood and peat agree well.

\section{ISGS-86. Bankston Fork}

$$
\delta \mathbf{C}^{14}=+14 \pm \mathbf{6}^{\%} \%
$$

Modern

Charcoal in silt from Williamson Co., NE $1 / 4$ NW1/4 NW1/4 Sec. 24, T.9S, R.4E, $7.5 \mathrm{~km} \mathrm{E}$ of Crab) Orchard, Illinois $\left(37^{\circ} 43^{\prime} 53^{\prime \prime} \mathrm{N}\right.$ Lat, $88^{\circ} 43^{\prime} 15^{\prime \prime}$ W Long). From top of probable lake sediments. Coll. 1971 by J. C. Frye, A. B. Leonard, and H. B. Willman; subm. by J. C. Fryc. Comment (J.C.F.): siltation on top of deposits of Lake Saline is still in progress.

\section{Little Cypress Ditch series}

\section{ISGS-88. Whole sample}

ISGS-95. >200 mesh

ISGS-96. $<200$ mesh
$17,510 \pm 330$ 15,560 B.C.

$23,500 \pm 960$ 21,550 в.c.

$19,160 \pm 690$ 17,210 в.C.

Organic-rich clayey sand from Gallatin Co., NW1/4 NW1/4 NW1/4 Sec. 20, I.9S, R.9E, $1.2 \mathrm{~km} \mathrm{NW}$ of Junction, Illinois $\left(37^{\circ} 43^{\prime} 54^{\prime \prime} \mathrm{N}\right.$ Lat, $88^{\circ} 14^{\prime} 52^{\prime \prime} \mathrm{W}$ Long). From Equality Formation. Coll. 1971 by 
J. C. Frye, H. B. Willman, and A. B. Leonard; subm. by A. B. Iconard, Univ. Kansas. Comment: sample contained coal fragments; therefore was sieved in order to minimize contamination. Small age difference between coarse sample with visible coal and fine fraction without visible coal indicates all 3 dates are probably maximum. Slightly younger age of ISGS-88 points out heterogeneous coal contamination.

\section{Big Cypress Ditch series}

Site in Gallatin Co., NE1/4 NW1/4 SW1/4 Sec. 20, T.9S, R.9E, 0.5 $\mathrm{km}$ NNW of Junction, Illinois ( $37^{\circ} 43^{\prime} 47^{\prime \prime} \mathrm{N}$ Lat, $88^{\circ} 13^{\prime} 31^{\prime \prime}$ W Long). Coll. 1971 by J. C. Frye and H. B. Willman; subm. by J. G. Fryc.

\section{ISGS-101. Mollusk shells}

$12,780 \pm 100$

From top 60 cin of 2 du ment (J.C.F.): clates pond fauna overlying youngest episode of outwash fill.

\section{ISGS-103. Unionid shell}

$$
13,030 \pm 190
$$

From 1 min bell (J.C.F): confirm date of youngest faun, silty lake filling. Comment mediately above youngest outwash fill.

\section{ISGS-104. Wood fragments}

$$
\delta \mathrm{C}^{14}=-10 \pm 17 \%
$$

From organic-rich silt, 1 to $1.2 \mathrm{~m}$ below surface. Comment: sample known to contain modern roots, but only wood not appearing to be root material was used. Date indicates most of wood in sample was from modern roots.

\section{ISGS-90. Fancy Prairie}

Muck with wood fragments from Menard Co., SWl $\mathrm{SW}_{1 / 4} \mathrm{SW} / 4$ Sec. 24, I.18N, R.5W, $1.3 \mathrm{~km}$ SW of Fancy Prairic, Illinois (39 59' $30^{\prime \prime}$ N Lat, $89^{\circ} 37^{\prime} 00^{\prime \prime} \mathrm{W}$ Long). From basal $45 \mathrm{~cm}$ of Robein Silt. Coll. 1971 by L. R. Follmer and W. H. Jolnson; subm. by L. R. Follmer, Illinois state Geol. Survey. Comment (I.R.F.): organic material began accumulating in early to middle Farmdalian time.

\section{ISGS-89. Center School \\ $20,500 \pm 130$ 18,550 в.с.}

Wood in silt from Coles Co., NW1/4 NW1/4 SW1/4 Sec. 15, T.11N, R.10E, $14 \mathrm{~km}$ SE of Clarleston, Illinois $\left(39^{\circ} 23^{\prime} 45^{\prime \prime} \mathrm{N}\right.$ Lat, $88^{\circ} 4^{\prime} 50^{\prime \prime}$ W Iong). From Robein Silt. Coll, 1971 by W. H. Johnson and L. R. Follmer; subm. by W. I. Johnson. Comment (W.H.J.): indicates approx. time Robein Silt was buried by drift derived from a Woodfordian glacier at $S$ margin of Woodfordian ice front. 


\section{Oakland series}

From Coles Co., center SW $1 / 4$ NE1/4 Sec, 14, T.14N, R.10E, $1.2 \mathrm{~km}$ WNW of Oakland, Illinois (39 $39^{\prime} 44^{\prime \prime} \mathrm{N}$ Lat, $88^{\circ} 03^{\prime} 30^{\prime \prime} \mathrm{W}$ Long). Coll. 1971 and subm. by J. P. Ford, Illinois State Geol. Survey.

ISGS-93. Organic-rich silt 70F17

$26,900 \pm 1100$

From base of Robein Silt. Comment (J.P.F.): reveals oldest age of Robein Silt in NE Coles Co. and, with date from nearby borehole of $20,000 \pm 400$ (I-2519, umpub.), dates approx. span of unit accumulation.

\section{ISGS-94. Organic-rich till 70F17}

$24,600 \pm 1300$

From ca. $30 \mathrm{~cm}$ above base of till underlying Glenburn Till. Comment (J.P.F.): till overlics Robein Silt ranging from ca. 20,000 to 27,000 yr B.P.; date suggests incorporation of Robein Silt in lower portion of till.

\section{ISGS-99. Sugar Creek Valley, Boring 8}

$$
22,700 \pm 1100
$$

Calcareous, organic-rich silt from Sangamon Co., NW1/4 NE $1 / 4$ SW $1 / 4$ Sec. 28, T.16N, R.4W, $4 \mathrm{~km} \mathrm{E}$ of Springfield, Illinois $\left(39^{\circ} 47^{\prime} 50^{\prime \prime} \mathrm{N}\right.$ Lat, $89^{\circ} 33^{\prime} 00^{\prime \prime} \mathrm{W}$ Long). From Robein Silt at $11 \mathrm{~m}$ depth. Coll. 1971 by W. H. Johnson; subm. by J. A. Miller, Univ. Illinois. Comment (J.A.M.): silt represents last episode of alluvial sedimentation in Sugar Creek, a tributary to Sangamon R., prior to lacustrine sedimentation in tributary valley. Ponding occurred when Sangamon R. tributaries beyond Woodfordian ice front were dammed by outwash.

\section{ISGS-102. Sangamon River Valley, Boring 9}

$24,640 \pm 430$ 22,690 в.C.

Organic-rich silt from Sangamon Co., NW $1 / 4$ SW1/4 NE1/4 Sec. 22, T.16N, R.4W, $6.4 \mathrm{~km} \mathrm{E}$ of Springfield, Illinois $\left(39^{\circ} 49^{\prime} 30^{\prime \prime} \mathrm{N}\right.$ Lat, $89^{\circ} 31^{\prime} 30^{\prime \prime}$ W Long). From Robein Silt at depth 11.0 to $12.5 \mathrm{~m}$. Coll. 1971 by W. H. Johnson; subm. by J. A. Miller. Comment (J.A.M.): represents last episode of alluvial valley fill prior to Woodfordian outwash aggradation in Sangamon Valley.

\section{B. Other localities}

ISGS-58. Port Talbot \# I

$44,100 \pm 1100$

42,150 в.C.

Peat from Elgin Co., Dunwich Con. XI, Lot 18, S end, $15 \mathrm{~km}$ WSW of Port Stanley, Ontario $\left(42^{\circ} 38^{\prime} \mathrm{N}\right.$ Lat, $81^{\circ} 23^{\prime} \mathrm{W}$ Long). From Port Talbot II Interstadial, at least $3 \mathrm{~m}$ below Lake Erie water level; broken out by waves and redeposited on present beach. Coll. 1958 and subm. by A. Dreimanis, Univ. W Ontario. Comment (A.D.): date agrees well with those of 3 other labs. (Drcimanis et al., 1966) on peat balls from organic deposits of Port Talbot Interstadial. 


\section{Louisiana series}

\section{ISGS-60. Florida Parishes No. II-2}

$$
\delta \mathbf{C}^{14}=+114 \pm 6 \%
$$

Modern

Wood in pebbly sand from Tangepahoa Co., Sec. 16, T.4S, R.7E, $2.5 \mathrm{~km} \mathrm{~S}$ of Amite City, Louisiana $\left(30^{\circ} 42^{\prime} \mathrm{N}\right.$ Lat, $90^{\circ} 30^{\prime} \mathrm{W}$ Long). From late Pleistocene pebbly sand underlying "Prairie Terrace" surface. Coll. 1970 and subm. by E. G. Otvos, Louisiana State Univ.

\section{ISGS-62. Florida Parishes No. II-4}

$$
\delta \mathbf{C}^{14}=-17 \pm 9^{\prime} / c 0
$$

Wood in pebbly sand from E Baton Rouge Parish, Sec. 42, T.4S, R.3E, $1.4 \mathrm{~km}$ ESE of Baywood, Louisiana $\left(30^{\circ} 41^{\prime} \mathrm{N}\right.$ Lat, $90^{\circ} 53^{\prime} \mathrm{W}$ Long). From pebbly sand underlying intermediate Amite R. Terrace. General Comment (E.G.O.): samples from hydraulic dredging over large pit area: exact location not known. Dates indicate wood is not from units being dredged.

\section{ISGS-72. Richland Co. 533 \\ $14,290 \pm 130$ 12,340 B.c.}

Wood in organic-rich silt with leaf and twig litter from Richland Co., SW $1 / 4$ SE1/4 NW1/4 Sec. 17, T.23N, R.18W, $4.8 \mathrm{~km}$ SE of Shiloh, Ohio (40 $57^{\prime} 15^{\prime \prime} \mathrm{N}$ Lat, 82 $32^{\prime} 55^{\prime \prime}$ W Long). From "forest bed" 15 $\mathrm{cm}$ thick, underlain by Hiram Till and overlain by gyttja and organicrich silt. Coll. 1970 and subm. by S. M. Totten, Hanover College, Hanover, Indiana. Comment (S.M.T.): date is minimum for deglaciation of Hiram (Woodfordian) ice from N-central Ohio and represents earliest accumulation of organic matter in region following deglaciation.

\section{Ernst Bros. Sand and Gravel Pit series}

Site in Oraukec Co., S1/2 NW1/4 Sec. 17, T.9N, R.21E, $4 \mathrm{~km} \mathrm{NW}$ of Mequon, Wisconsin (43 $15^{\prime} 00^{\prime \prime} \mathrm{N}$ Lat, $88^{\circ} 00^{\prime} 30^{\prime \prime} \mathrm{W}$ Long). Coll. 1970 by J. C. Frye, H. B. Willman, and J. P. Kempton; subm. by J. C. Frye.

ISGS-73. P.7258

Wood from base of upper forest bed in bog sediments. Comment (J.C.F.): dates termination of pond sediments contemporancous with stand of Valclers glacier nearby.

\section{ISGS-75. P.7246}

$12,500 \pm 120$ 10,550 B.C.

Wood from base of Twocreekan forest bed. Comment (J.C.F.): date is check run on wood from below pond deposits. Previously dated 12,410 \pm 100 (WIS-347, R., 1970, v. 12, p. 342).

\section{ISGS-76. Two Creeks}

$$
12,020 \pm 110
$$

Wood in bedded red silt from Manitowoc Co., NE $1 / 4$ NE $1 / 4$ NE $1 / 4$ Sec. 2, T.21N, R.24E, $3.2 \mathrm{~km} \mathrm{NE}$ of Two Creeks, Wisconsin $\left(44^{\circ} 15^{\prime}\right.$ 
N Lat, $87^{\circ} 34^{\prime} \mathrm{W}$ Long). Wood cut from $\log$ in lower part of forest bed in red silt and clay. Coll. 1970 by J. C. Frye and H. B. Willman; subm. by J. C. Fryc. Comment (J.C.F.): date is check run on lowest wood at Two Creeks type locality.

\section{ISGS-91. De Baca Co. shells}

Shells of gastropod (Iymnaea) from De Baca Co., New Mexico, SE $1 / 4$ Sec. 23, T.3N, R.25E, $2.3 \mathrm{~km} \mathrm{~W}$ of Fort Sumner, New Mexico $\left(34^{\circ} 27^{\prime}\right.$ $\mathrm{N}$ Lat, $104^{\circ} 17^{\prime} \mathrm{W}$ Long). From terrace deposit along Pecos R. Coll. 1971 by J. C. Frye and A. B. Leonard; subm. by J. C. Frye. Comment (J.C.F.): dates an intermediate terrace of Pecos R. Valley.

\section{ISGS-92. Acme Station}

$18,100 \pm 370$

Shells, mostly gastropod (Lymnaea) in sand and silt from Chaves Co.,

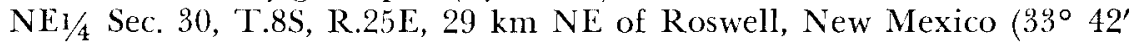
N Lat, $104^{\circ} 26^{\prime} \mathrm{W}$ Long). From late Pleistocene sediments in formerly undrained depression that supported aquatic molluscan fauna. Coll. 1971 by J. C. Frye and A. B. Leonard; subm. by J. C. Frye. Comment (J.C.F.): dates fossiliferous pond deposit on a significant terrace level, E side of Pecos R. Valley.

\section{ARCHAEOLOGIC AND TREE RING SAMPLES}

\section{Brynjulfson Cave series}

From Boone Cio., SW1/4 NE $1 / 4$ SW $1 / 4$ Sec. 16, T.47N, R.12W, 19 $\mathrm{km} \mathrm{S}$ of Columbia, Missouri (38 $51^{\prime} 07^{\prime \prime} \mathrm{N}$ Lat, $92^{\circ} 16^{\prime} 50^{\prime \prime} \mathrm{W}$ Long). Subm. by P. W. Parmalee, Illinois State Mus., Springfield, Illinois.

\section{ISGS.66. Brynjulfson Cave \#2}

$2460 \pm 230$

Collagen fraction of bone sample from darker of 2 horizontal soil layers, ca. $1 \mathrm{~m}$ above cave floor. Coll. 1969 by P. W. Parmalee and R. D. Ocsch. Comment (P.W.P.): bone from animals comprising recont faunal species complex of cave. Date within time period anticipated for species represented and indicates more recent deposition of matrix than expected in neighboring Brynjulfson Cave \#1.

\section{ISGS-70. Brynjulfson Cave \#1}

$9440 \pm 760$

Collagen fraction of bone coll. randomly from cave fill of ca. $12 \mathrm{~m}$ distance. Coll. 1962 by M. G. Melil. Comment (P.W.P.): probably dates most recent period of occupation of cave by peccary, dire wolf, extinct skunk, etc.

ISGS-77. Tree ring \#12 $546 \pm 70$

Wood (Juniperts virginiana L.) cut in 1967. Portion dated from core, containing ca. 125 growth rings. Tree had 617 growth rings. Subm. 
by J. C. McGregor, Univ. Illinois. Comment: used as check sample; portion dated is known to have grown between Ca. A.D. 1350 and 1475 .

\section{ISGS-105. Puna 01}

$8620 \pm 300$

Gyttja intercalated in volcanic ash from Humahuaca, $150 \mathrm{~km}$ NW of Jujuy, Argentina (29० $17^{\prime} 00^{\prime \prime} \mathrm{S}$ Lat, $65^{\circ} 42^{\prime} 00^{\prime \prime} \mathrm{W}$ Long). From Holocene fluvial terrace, Esquinas Blancas Formation. Coll. 1971 and subm. by Jorge Fernández, Mina Aguilar-Pcia de Jujuy, Argentina. Comment (J.F.): 1st date for Argentine Puna. Establishes base of Holocene sediments and approx. date for human industry "saladillense." Also dates last postglacial volcanic eruption.

\section{RIFERINCIS}

Coleman, D. I)., 1972, Illinois State Geological Survey radiocarbon dates III: Radiocarbon, v. 14, p. 149-154

Dreimanis, A., I Terasmac, J., and Mckenzie, G. D., 1966, The Port Talbot interstade of the Wisconsin glaciation: Canadian Jour. Farth Sci., v. 3, p. 305-325.

Crüger, E., 1970, The development of the vegetation of southern Illinois since late Illinoian lime (preliminary report): Rév. Géog. Physique el Géol. Dynamique (2), v. 12 , 110. 2, p. 143-148

Jacobs, A. M., 1970, Persistence of lake basins in southern Illinois, U.S.A., from late Illinoian time to the present: Rév. Géog. Physique et Géol. Dynamique (2), v. 12, no. 2, p. 137-142.

Kim, S. M, and Ruch, R. R., 1969, Illinois State Geological Survey radiocarbon dates I: Radiocarbon, v. 11, p. 394-395.

Kim, S. M., Ruch, R. R., and Kempton, J. P., 1969, Radiocarbon dating at the Illinois State Geological Survey: Illinois Geol. Survey Environmental Geol. Note 28, $19 \mathrm{p}$

Lineback, J. A., Ayer, N. J., and Gross, D. L., 1970, Stratigraphy of unconsolidated sediments in the southern part of Lake Michigan: Illinois Geol. Survey Environmental cicol. Note $35,35 \mathrm{p}$

Noakes, J. E., Kim, S. M., and Akers, L. K., 1967, Recent improvements in benzene chemistry for radiocarbon dating: Geochim. et Cosmochim. Acta, v. 13, p. $109+1096$.

Noakes, J. E., Kim, S. M., and Stipp, J. J., 1965, Chemical and counting advances in liquid scintillation radiocarbon dating: 6th internatl. conf. radiocarbon and tritium dating Proc., Conf-650652, p. 68-98.

Wilman, H. B., Leonard, A. B., and l'ye, J. C., 197I, Farmdalian lake deposits and fallnas in northern Illinois: Illinois Cicol. Survey Circ, 467, 12 p. 